\title{
Rockfall Characterization and Structural Protection in the Siddhababa Section of Siddhartha Highway H10, Nepal
}

\author{
Kaushal Raj Gnyawali, Ranjit Shrestha, Anil Bhattarai, Pramod Rangu Magar \\ Anup Raj Dhungana, Imjal Sukupayo and Rasla Dumaru \\ Department of Civil Engineering, Khwopa College of Engineering, Tribhuvan University, Nepal \\ corresponding author: kaushal.raj.gnyawali@gmail.com
}

\begin{abstract}
Many national highways of Nepal are periodically facing the rockfall events, causing fatal accidents. The Siddhababa section of Siddhartha Highway is a lively example of an active rockfall zone where the highly steep slope geometry in combination to the unfavourable inclination of the rock joints with the road alignment primarily cause the rockfall. Recent accidents of a jeep and a bus have created much concern on rockfall in the area. But still, we do not possess any type of structural countermeasure to overcome this scenario. To address this problem, our study aims at firstly characterizing the rockfall in the area and then on proposing structural countermeasure as rockfall barriers, rock netting and rockshed, and assisted with rock bolting, based on simulation studies and analysis of the rockfall scenario in Rocscience Rocfall ${ }^{\circledR}$ program.
\end{abstract}

Keywords: rockfall, Rocscience Rocfall ${ }^{\circledR}$ program, rockfall barrier, rock netting, rock shed, rock bolting

\section{Introduction}

Rockfall from the roadside rock slopes is a major hazard in the rock cut slopes of mountainous countries like Nepal. At present, many national highways of Nepal are sporadically facing the rockfall events, causing fatal accidents in an alarming manner. The Highway Rock Slope protection is still unable to overcome its infancy state in Nepal and this is justified, because we could hardly see some structural countermeasure in the form of rock bolts and counterforts in our roadside slopes. The Siddhababa section of Siddhartha Highway is among many of the highway sections in Nepal where fatal rockfall events have a long timeline of momentous number of casualties. Excessively steep slope geometry in combination to the unfavorable rock joints with the road alignment set up a platform for continuous detachment of rocks from the rock slopes and their falls onto the Highway in the area. This has created a noxious environment for the travelers through such Highway sections. The most recent cases of rockfall in the area include the rock mass falling on a jeep killing two doctors [18] and more recently, a bus swept away by debris flow killing 3 people and more missing [8]. This study aims at characterizing the rockfall in the area and proposing structural countermeasure based on review of scientific literature and some preliminary analysis in Rocscience Rocfall ${ }^{\circledR}$ program [20]. However, the highway sections in which the structures herein proposed are based on simplified simulation analysis and visual assessment of vulnerability of the sections. More hazardous sections need to be identified based on detailed 3D simulation studies. This is a limitation of this study. 


\section{Rockfall: Definition and Process}

The rockfall is a slope process involving the detachment of an unstable rock mass or fragments from the slope surface and the subsequent downslope movement by ways of falling, bouncing, rolling or sliding and finally stopping at a relatively flat area or a barrier $[19,22,28,15]$. If there are any people or facilities within the area of rockfall movement and certain losses are caused it is called the rockfall hazard. It may be caused by jointing, weathering, erosion of surrounding material during heavy rain storms, freeze-thaw cycles, pore pressure increase due to rainfall infiltration in the rock joints, earthquake, and root growth or leverage by roots moving in high winds [19, 22, 29, 16]. It is a rapid, mostly natural and rather spontaneous hazard. The Varnes [22] classification of landslides classifies rockfall as a type of landslide which can occur singly or in clusters, but with little dynamic interaction between the most mobile moving fragments, which interact mainly with the substrate (path) and possessing extremely rapid velocities [13].

The rockfall kinematics and dynamics depend on block geometry, block mass, slope topography, surface materials and vegetation. The geometrical properties of the parent rock discontinuities, such as orientation, density, persistence, and roughness control the occurrence of rockfall events mainly and once the failure occurs, blocks move downslope following irregular paths and gain velocity on free air falls as potential energy is converted into kinetic energy [9]. On each impact, rolling or sliding, the total energy gets dissipated until the resisting ground frictional force or barrier reaction overcomes the energy of the block and stops it $[9,25,26]$. The rockfall frequency is highly variable and depends on site characteristics such as: morphology and geology of the source area and slope control the provision of materials and the spatial and temporal distribution of the triggering processes [16].

\section{Study Area}

The Study area lies in Palpa district of Lumbini Zone, Western Development Region Nepal, near the town of Butwal. It is a stretch of the Siwalik hills extending about $2.6 \mathrm{~km}$ from the "Welcome to Palpa" gate to some $700 \mathrm{~m}$ ahead of Ramapithecas park area. Primarily, the rock mass contains three distinct joint sets + bedding. Typical rock type is Sandstone of specific gravity 2.45 to 2.60 , depending upon the degree of weathering and together we find mudstone beds at some places.

Previous studies conducted in the section include Hazard Mapping of the unstable slopes in the area [21], Hazard Rating and Event Tree analysis for assessing rockfall risks in 12 different sections in the area [14]. Two independent study reports and mitigation proposals have already been submitted to Department of Roads (DOR), [4,5] in the subsequent years. However, the implementation phase seems to take some time. 


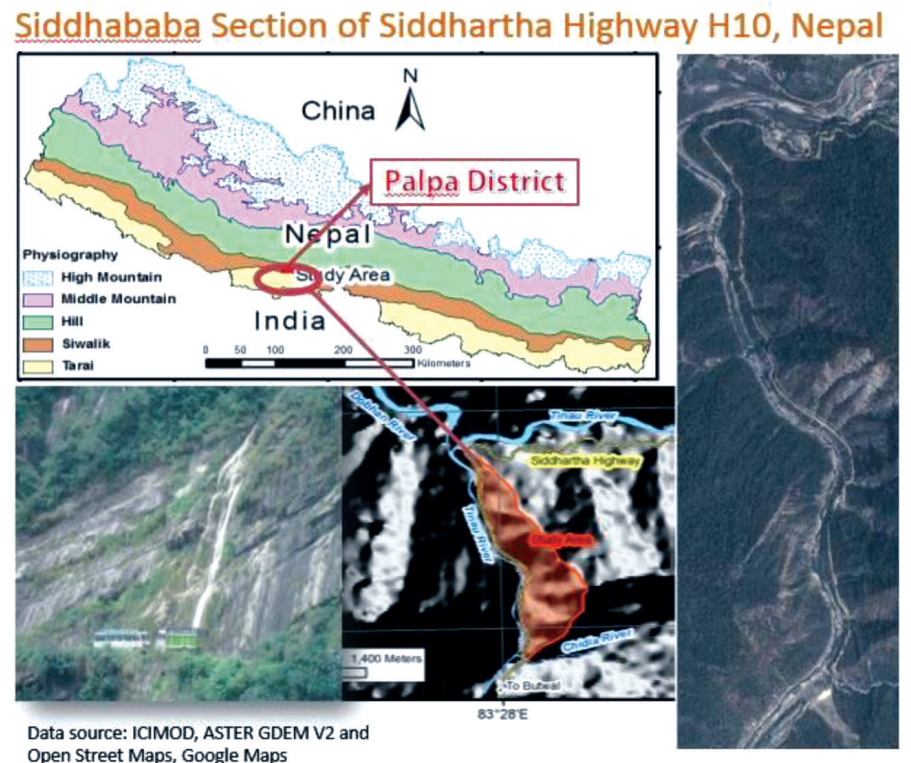
Open Street Maps, Google Maps

Fig. 1. The study area

\section{Rockfall Characterization}

Plane failure is the most prominent type of failure caused due to a SW facing joint set. And together, a short reach of about $400 \mathrm{~m}$ of Wedge failure region is also found from Chahara area to some $100 \mathrm{~m}$ ahead of Ramapithecas Park between SE and SW facing joint sets.

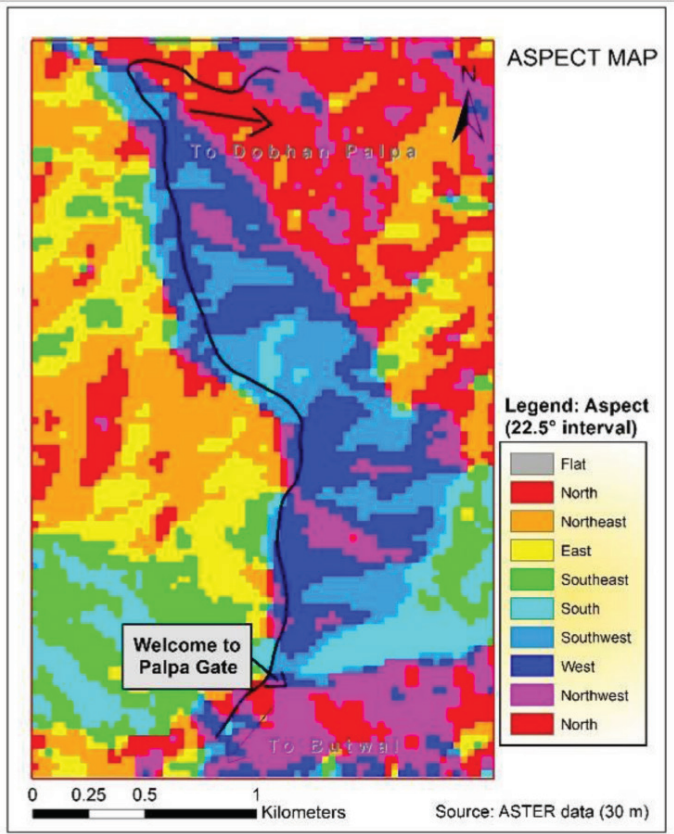

Fig. 2. Aspect map of the rock slopes

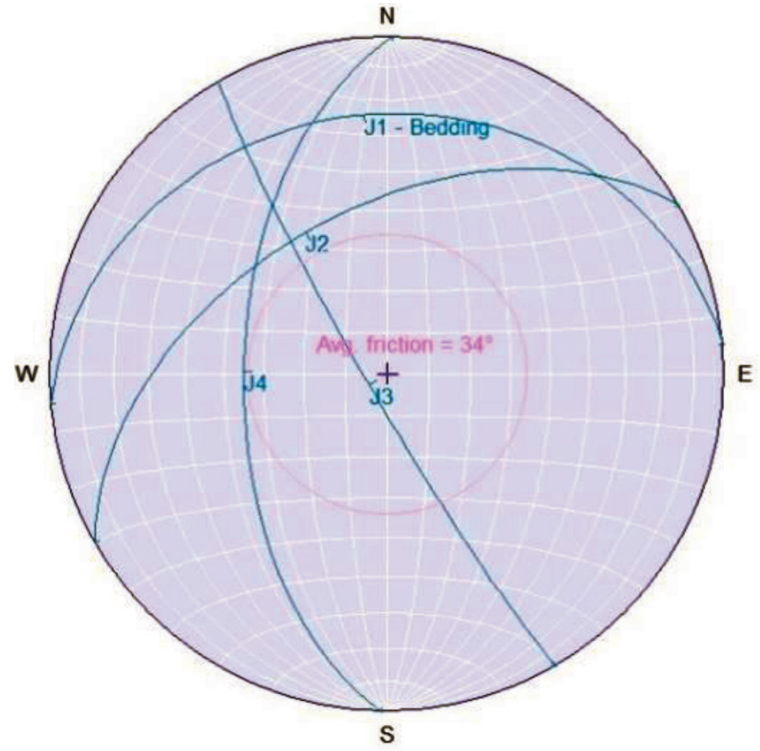

Fig. 3. Typical stereo plot for the 4 joint sets prevailing in the area 


\subsection{Cause of Rockfall in the Area}

Table 1. Identification of the cause of rockfall in the area.

\begin{tabular}{|c|c|c|c|}
\hline ts & in & $\begin{array}{l}1.3 \text { Weakening of } \\
\text { ockMass }\end{array}$ & \\
\hline $\begin{array}{l}\left.\text { tavg. } 60^{\circ}\right) \text {, and } \\
\text { nment of the } \\
\text { se the orient } \\
\text { nerability of rocks s } \\
\text { ure. The basic fric } \\
\text { le of Sandstone fo } \\
\text { he area varied betv }\end{array}$ & $\begin{array}{l}\text { 1s of sands } \\
\text { at places, } \\
\text { beds were } \\
\text { The mudstor } \\
\text { quickly an } \\
\text { by the rush } \\
\text { or rain w } \\
\text { thus the } \\
\text { jointed rock } \\
\text { lose their su } \\
\text { start falling. }\end{array}$ & $\begin{array}{l}\text { area receives } \\
\text { precipitation and } \\
\text { of the time, the } \\
\text { s show no infill. } \\
\text { pore pressure } \\
\text { up due to rainfall } \\
\text { ration; \& together, } \\
\text { hering is occurring } \\
\text { faster rate, thereby } \\
\text { uraging rock } \\
\text { ing and fall. The } \\
\text { fall is then being } \\
\text { ered by road } \\
\text { tions caused by } \\
\text { y and busy traffic. }\end{array}$ & $\mathrm{n}$ \\
\hline
\end{tabular}

\subsection{Slope Failure Modes}

Based on the observations and literature review, the slope failure/rockfall problem character in the area is grouped into three simple modes:

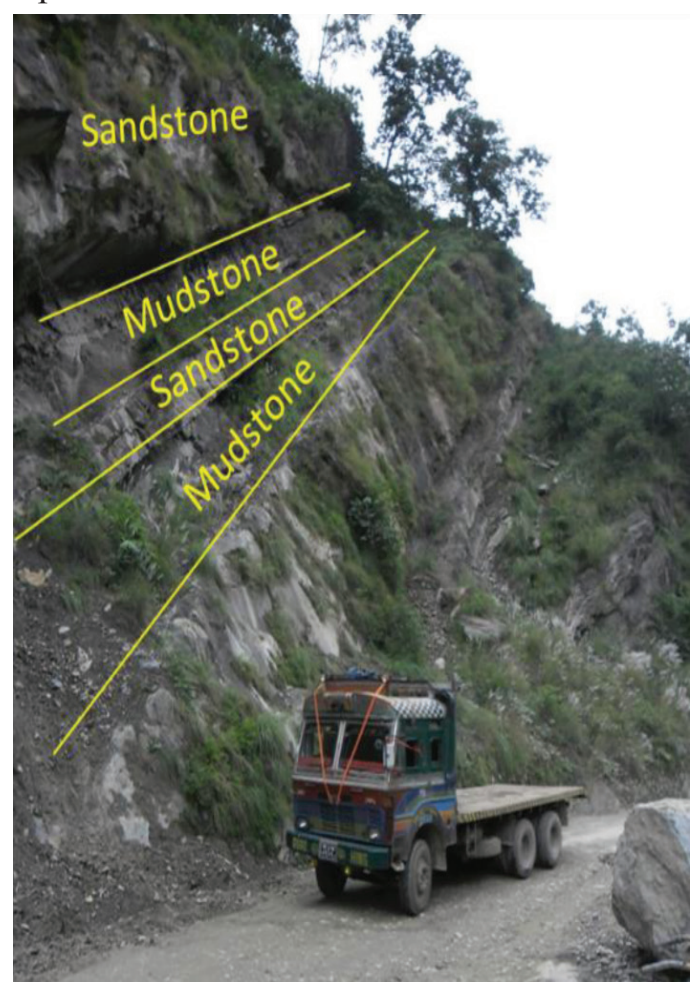

Fig. 4. The primary bedding is of sandstone and mudstone occurs at places; the mudstone bed erodes/wash out by rain then the overlying jointed rock loses support thus slips by plane failure 


\subsubsection{Block failure}

Large blocks (average size. $1 \mathrm{~m}^{3}$ to $20 \mathrm{~m}^{3}$ ) splitting from the surface and falling on the road with mostly plane failure mechanism.

\subsubsection{Slope scar Collapse}

A portion of the rock slope fails by shear failure causing minor scale landslide leaving scar on the slope.

\subsubsection{Gully Erosion/Debris flow}

Many gully channels are being formed which are activated periodically during monsoons and carry large volume of debris at high speeds towards the road.

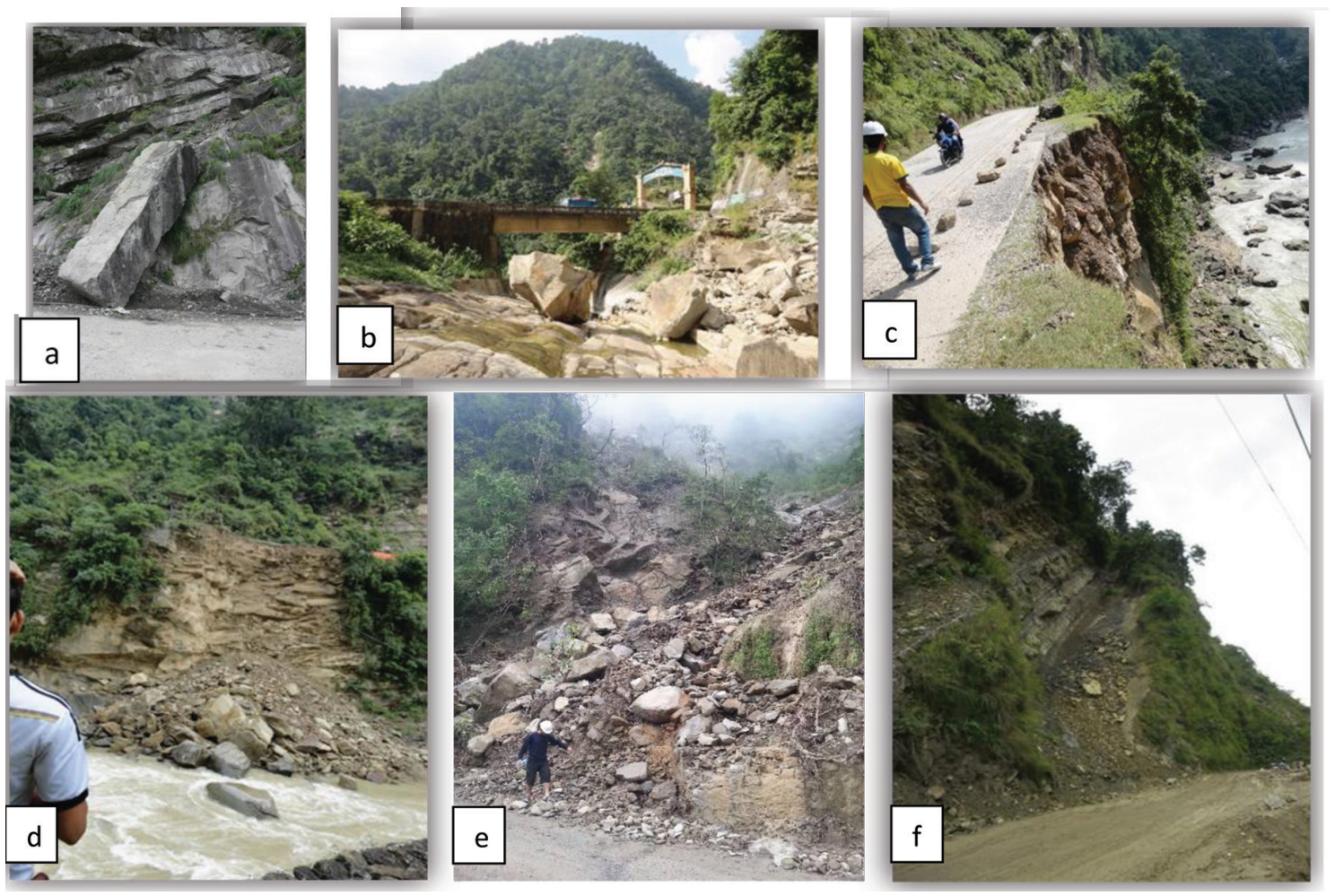

Fig. 5. Rock slope failure problem (a, b), Block failure type (c, d), Slope scar collapse and Debris flow (e \& f).

The recent rockfall of [18] is a slope scar type fall of approximately $18-20 \mathrm{~m}^{3}$ volume and of [8] is Debris flow type fall.

\section{Rockfall Protection}

Rockfall protection includes risk assessment, identification of mitigation options, and design of structural countermeasures which requires a careful quantification of rockfall onset susceptibility and block size distributions in the potential source areas, expected rockfall trajectories, distribution and intensity of impacts, and magnitude and statistical variability of involved kinematic and 
dynamic quantities (i.e. velocity, kinetic energy, fly height [1]). A large variety of protection measures against rockfalls exist which include: natural protection by means of forest, semi natural structures such as embankments and ditches and fully artificial structures such as fences, attenuators, galleries or walls [12, 24]

\section{Rockfall Modelling}

To predict the rockfall threat and for proper design and dimensioning of the protection measures, we need to estimate the rockfall run-out distance and then quantify their kinetic energies, jump heights and impact loads for each point along their fall paths in a spatial domain [24, 7]. We require the simulation results in the design process of appropriate remedial measures to rockfall such as ditches, barriers, rock catch fence and attenuators, draped mesh, rock sheds and embankments [24, 28 ] and thence we can determine the appropriate physical parameters of a preventive structure, such as position, type, strength, length, height and the magnitude and direction of the impact loads [2]. Some literature with holistic approach on design of rockfall protective structure from numerical modelling of rockfall could be $[17,15]$. For the purpose two methods are practised: full scale tests or rockfall simulation by commercially available software. The latter is preferred because it is both time and cost effective solution. However careful attention should be paid towards collecting detailed field data and the calibration of the model is a prime concern in such simulation works.

The rockfall source regions can be defined as points (e.g., isolated outcrops or localized failures), lines (e.g., cliff-top envelopes), or areas [9] and then the rockfall dynamics and kinematics are computed employing either empirical, process based or complete three dimensional rigid bodyterrain interaction approaches. Dorren [6] categorized all the existing rockfall models in three main groups: (1) empirical models, (2) process based models and (3) GIS based models. Recent works of Volkwein et al. [24] classifies the rockfall models into 2D models (user defined slope profile/fall paths), 2.5D models (2D models assisted by GIS to derive pre-defined slope profiles/fall paths) and 3D models (calculate the rockfall trajectory in a full three dimensional environment). However, the two dimensional modelling is preferred when the geometrical and dynamic effects of the 3D topography can be ignored, for example on planar cliff-talus slopes, on slopes characterized by low roughness [3], or on slopes with little or no vegetation and in steep gullies or valleys mainly because of their computational efficiency and currently enough literature review is available for them. A good literature review for the purpose would be the works of Wyllie [27].

\section{Structural Protection Proposal Approach}

A detailed field visit is done and data related to slope, previous rockfall events, existing and previous block sizes, slope profiles along most critical sections, material on the slope and structural discontinuity data is collected in order to simulate the rockfall events in Rocsciece Rocfall ${ }^{\circledR}$ [20] program and for other analyses. Sections are evaluated based on: 1) frequency of rockfall events/ hazard 2) slope failure character 3) approximate energies of the falling blocks after analysis in Rocscience Rocfall ${ }^{\circ}$ 4) site accessibility and then appropriate structural countermeasures are proposed. Basically three types of protective structures are proposed: 1) Rockfall catch fence 2) Anchored rock mesh system and 3) Rock shed and rock bolting as an additional asset. These structures are proposed based on field based reconnaissance, and their suitability under the existing engineering geological conditions. Tentative energy range for rockfall barrier is from 1000KJoules to $3000 \mathrm{KJ}$ oules. The anchored rock mesh, aka rock netting is chosen for areas consisting of superficial rocks adjacent of the road. Block sizes ranging from about $0.3 \mathrm{~m}^{3}$ to $2 \mathrm{~m}^{3}$ formed due to structural jointing of the sandstone beds and destabilized by the erosion of mudstone layers 
inter-bedding could be draped with the rock nets for protection. The rock shed is proposed at Chahara section because of large size blocks, heights from which they could fall, very inaccessible steep terrain and abnormality in rock slope failure ranging from large rock falls to debris falls and dry landslides. In addition, some unstable blocks also need rock bolting. All in all, these systems should be used in an integrated form to prevent rockfall hazard in Siddhababa. For quick review of these structures, a brief documentation is available at [10]. A much detailed discussion is available at [26].

\subsection{Rock Catch Fence}

The Rockfall catch fence acts as a flexible barrier system absorbing the energy of the falling rock by the deflection of its components (ring nets or omega nets in particular, then friction brakes, cables, hinge frames and other deformable energy dissipating structures). A design suitable for a particular site depends on the topography, anticipated impact loads and bounce heights. A common feature of all the designs is their ability to withstand impact energy from rockfalls due to their construction without any rigid components [28].

\subsection{Anchored Rock Mesh}

These systems consist of covering the superficial rocks adjacent of the road and restraining their movement them on the slopes itself by steel meshing system guarded by the pattern rock bolts at intervals. These thus act as passive systems and are suitable to control mainly smaller blocks sliding from the weathered rock outcrops just adjacent to the road.

\subsection{Rock Shed}

This acts as a rigid structure and has a cushion layer at its top such that the energy of the falling rocks be absorbed significantly before causing any damaging effects to the roof. These could be constructed as cantilever type or base support type based on the site conditions. These are capable of restraining very high impact energies and are self-cleaning structures i.e. rocks are generally removed from the roof because of the sloping provided at the roof and no manual removal of the fallen rocks is required.

In addition to these, rock bolting is necessary for some blocks lying critically stable in some slopes.

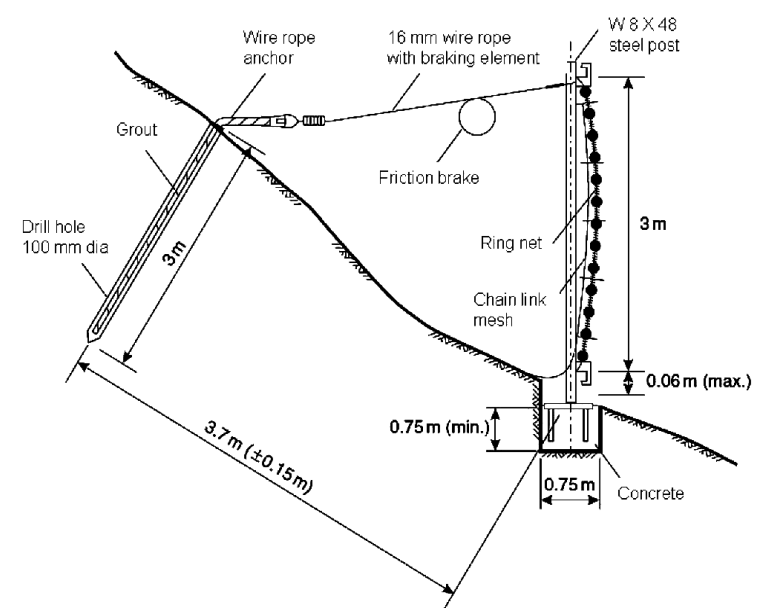

Fig. 6. Schematic of Rockfall barrier system discussed herein. Modified after [26] and courtesy Geobrugg Inc. 

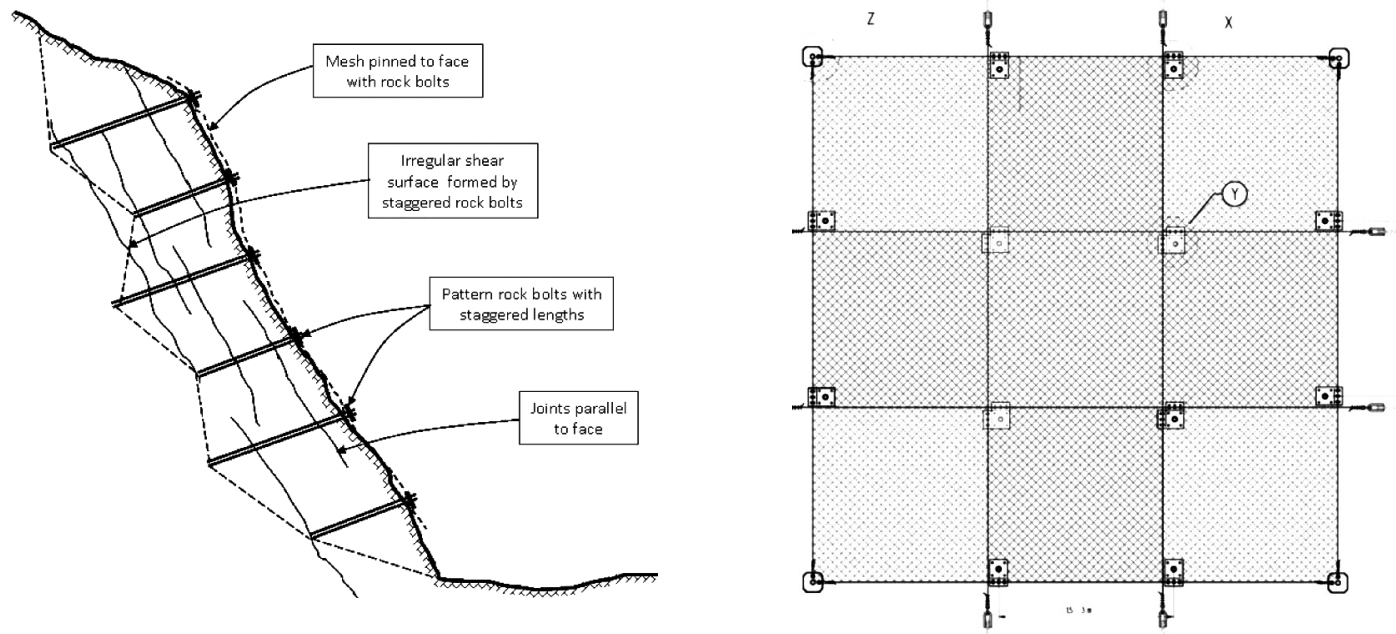

Fig. 7. Schematic of Anchored rock mesh system discussed herein: a) section view b) plan view.: Modified after [26] and courtesy Trumer Schutzbauten.
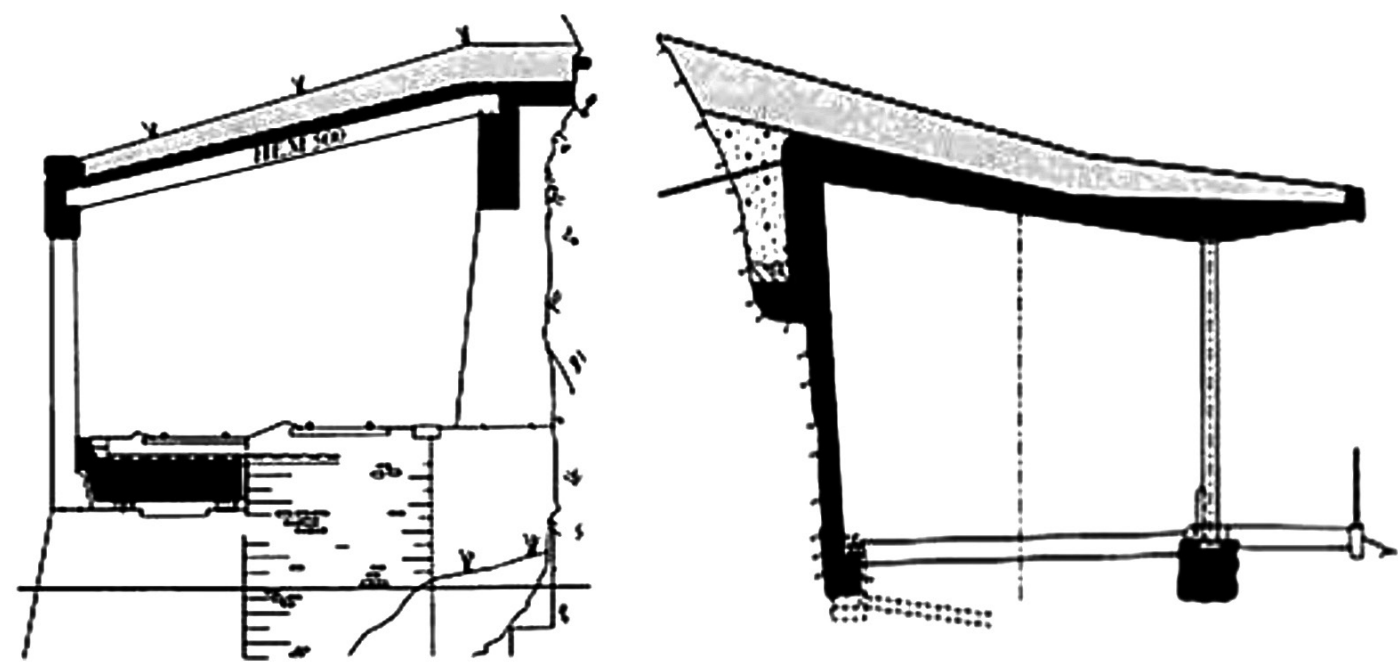

Fig. 8. Schematic of possible Rock shed configuration discussed herein. After Vogel [23]. 


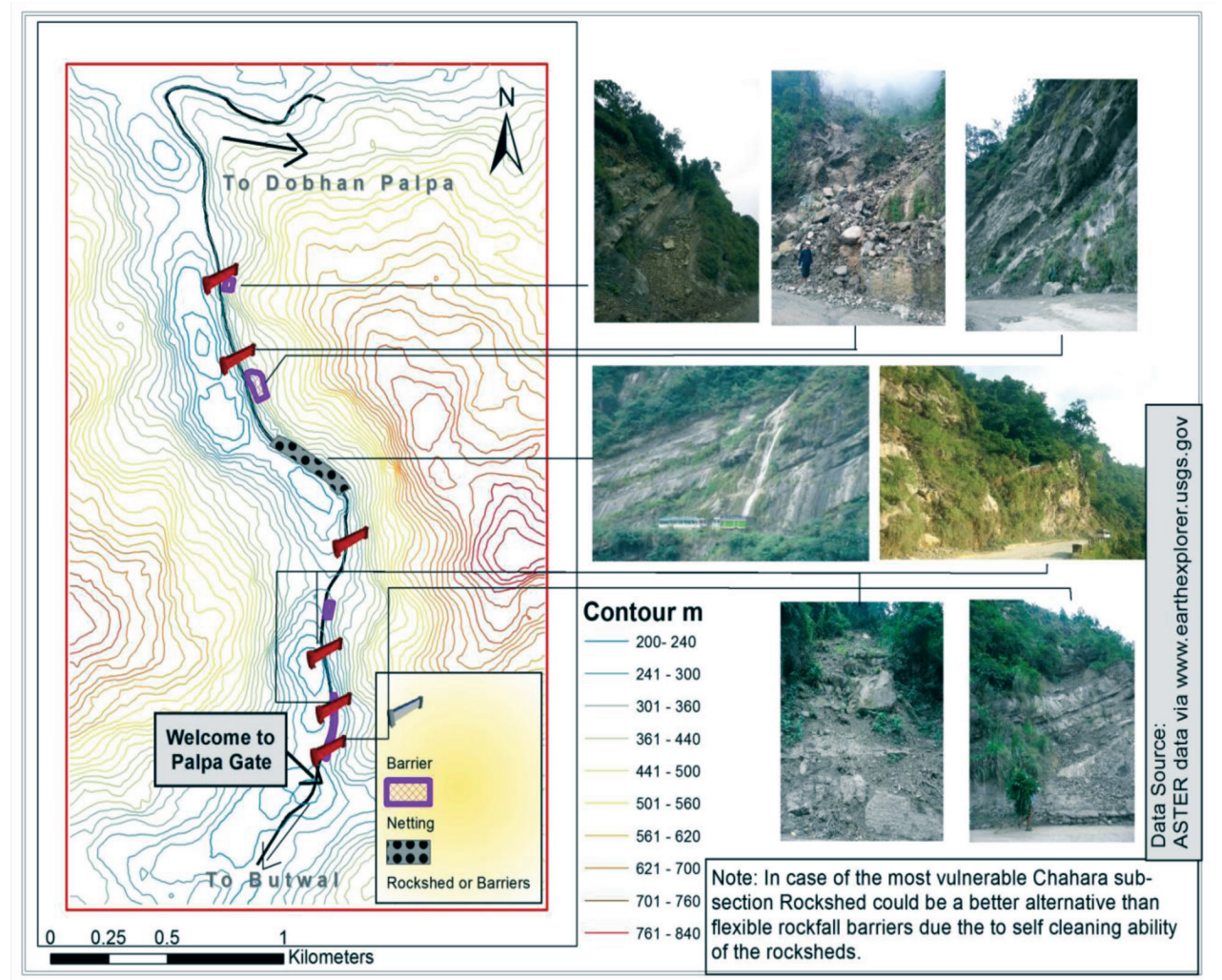

Fig. 9. Proposal of structural countermeasures
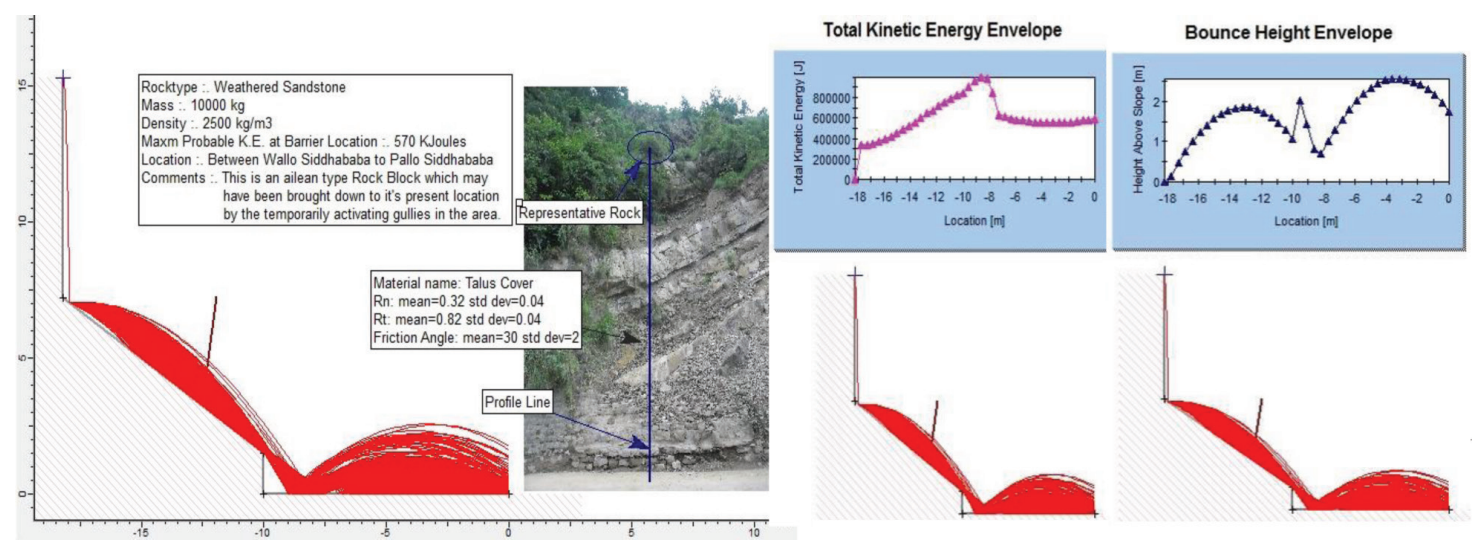

Figure 10. Sample analysis in Rocscience Rocfall ${ }^{\circledR}$ program.

\section{Results and Conclusion}

This study concludes that the rockfall character in the Siddhababa section of Siddhartha highway H10, Nepal is hazardous and needs structural countermeasures. Basically three types of slope failure occur: Block failure, Gully erosion and Slope scar collapse due to unfavourable orientation of the discontinuity sets with the road, breaking sequence of sandstone beds by mudstone, weathering 
and debris flow. The structural protection of rockfall in Siddhababa could be: 1) Rockfall barrier system, 2) Anchored rock mesh 'rock netting' system and 3) Rockshed. In addition, rock bolting is necessary for some critically stable blocks on slopes. Immediate need for installation of such novel structures seems necessary. However, the highway sections in which the structures herein are proposed are based on simplified simulation analysis and visual reconnaissance of vulnerability of the sections. More hazardous sections need to be identified based on detailed 3D simulation studies. This is a limitation of this study.

Acknowledgments: This research is an outcome of inspiration and support from Er. Sujan Maka, principal of Khwopa Engineering College, Bhaktapur, Nepal and Dr. Ranjan Kumar Dahal, Associate Professor (Engineering Geology), Tribhuvan University, Tri-Chandra Campus, Nepal. We are also thankful to the Department of Civil Engineering at Khwopa College of Engineering, Libali, Bhaktapur.

\section{References}

[1] Agliardi F and Crosta, GB (2013), Supporting Rockfall Countermeasure Design in Difficult Conditions. Landslide Science for a Safer Geoenvironment, III.

[2] Chen G, Zheng L, Zhang Y and Wu J (2012), Numerical Simulation in Rockfall Analysis: A Close Comparison of 2-D and 3-D DDA. Rock Mech Rock Eng. doi:10.1007/s00603-0120360-9.

[3] Crosta GB and Agliardi F (2004), Parametric evaluation of 3D dispersion of rockfall trajectories. Natural Hazards and Earth System Sciences 4, 589-598.

[4] Dahal RK (2014), Report submitted by Trumer Schutzbauten, Austria basen in Nepal through Himalaya Conservation Group to DRO. DOR Palpa.

[5] Dhakal S (2012), Report submitted by GHEaSES Intl. and BEAM Consult. to DRO. DOR Palpa.

[6] Dorren LK (2003), A review of rockfall mechanics and modelling approaches. Progress in Physical Geography, I(27), 69-87.

[7] Dorren L, Domaas U, Kronholm K and Vinc. (2011), Methods for Predicting Rockfall Trajectories and Run-out Zones. In S. Lambert, \& F. Nicot, Rockfall Engineering (pp. 143-168). London, UK: ISTE Ltd.

[8] Ekantipur (2015, August 8). Retrieved from Ekantipur.com: http://www.ekantipur. com/2015/08/08/top-story/bus-swept-away-by-landslide-3-killed/409128.html

[9] Frattini P, Crosta G B and Agliardi F (2012), Rockfall characterization and modeling. In J. J. Clague, \& D. Stead (Eds.), Landslides-Types, Mechanisms and Modeling (pp. 267-281). New York: Cambridge University Press.

[10] Gnyawali KR (2014), Document posted on personal blog. Rockslope Protection Works: Rockfall Catch Fence and Anchored Rock Mesh Protection System. Retrived from http://www. kaushalrajgnyawali.blogspot.com/

[11] Hoek E (2000), Analysis of Rockfall Hazards. In Practical Rock Engineering. Retrieved from http://www.rocscience.com/hoek/corner/9_Analysis_of_rockfall_hazards.pdf

[12] Hoek E and W JB (2005). Rock Slope Engineering (4th ed.). (D. C. Wyllie, \& C. W. Mah, Eds.) New York: Spon Press.

[13] Hunger O, Leroueil S and Picarelli L (2013), The Varnes classification of landslide types, an update. Landslides. 
[14] Kharel P and Dhakal S (2013), Hazard Rating and Event Tree Analysis for Assessing Rockfall Risks Along Siddhartha Highway in Siddhababa Area, Nepal. International Journal of landslide and Environment (IJLE), I(1), 41-42.

[15] Lambert S, Bourrier F and Toe D (2013), Improving three-dimensional rockfall trajectory simulation codes for assessing the efficiency of protective embankments. International Journal of Rock Mechanics \& Mining Sciences 60, 26-36.

[16] Luckman BH (2013), Processes, Transport, Deposition, and Landforms: Rockfall. In J. Shroder (Ed.), Treatise on Geomorphology 14 ed., 1, pp. 174-182.

[17] Moon T, Oh J and Mun B (2014), Practical design of rockfall catch fence at urban area from a numerical analysis approach. Engineering Geology 172, 41-56.

[18] Onlinekhabar (2015, June 17). Retrieved from Onlinekhabar.com: http://www.onlinekhabar. com/2015/06/289457/

[19] Ritchie A (1963), The Evaluation of Rockfall and its Control. Highway Research Record. Washington DC: National Academy of Sciences-National Research Council.

[20] Rocfall-Rocscience Inc, https://www.rocscience.com/rocscience/products/rocfall

[21] Thapa AB (2011), Rock slide hazard mapping along Siddhartha Highway (Chidiya Khola Dovan road section) with GIS application. MSc Dissertation, Institute of Engineering, Pulchowk/ Central Campus, Civil Engineering, Nepal.

[22] Varnes D (1978), Slope Movement types and processes. Washington DC: Transportation Research Board, National Research Council.

[23] Vogel T (2009), Rock fall protection as an integral task (Vol. 3). Zurich, Switzerland: Structural Engineering International. Retrieved from www.iabse.org

[24] Volkwein A, Schellenberg K, Labiouse V, Agliardi F, Berger F, Bourrier F, and et al. (2011), Rockfall characterization and structural protection - a review. Natural Hazards and Earth System Sciences, 2617-2651.

[25] Wyllie DC (2014), Calibration of rock fall modelling parameters. International Journal of Rock Mechanics \& Mining Sciences 67, 170-180.

[26] Wyllie DC (2014), Rockfall Engineering. CRC Press, Taylor and Francis Group.

[27] Wyllie DC (2014), Rock fall Engineering : Development and calibration of an improved model for analysis of rockfalls in highways and railways. $\mathrm{PhD}$ Thesis, The University of British Columbia, Vancouver.

[28] Wyllie DC and Mah CW (2005), Stabilization of rock slopes. In Rock Slope Engineering (pp. 310-319). Taylor \& Francis e-Library.

[29] Zhang L, Yang Z and Xu B (2004), Rockfalls and rockfall hazards. Journal of Engineering Geology 3, 225.

[30] (2010). Retrieved from Geobrugg: http://geobrugg.com/en

[31] (2014). Retrieved from Trumer Schutzbauten: http://www.trumer.cl/ 